психологии, 1998. - 288 с. З. Нечепоренко Л. С. Схематические наглядные пособия и методика их применения / Л. С. Нечепоренко. - Каменец-Подольский, 1967. - 231 с. 4. Педагогика / [Абдуллина О. А., Алемаскин М. А., Бабанский Ю. К. и др.] ; под ред. Г. Нойнера, Ю. К. Бабанского. - М. : Педагогика, 1984. - 368 с. 5. Педагогика школы :[учеб. пособ. для студ. пед. ин-тов] / под ред. Г. И. Щукиной. - М. : Просвещение, 1977. - 384c. 6. Столяр А. А. Педагогика математики / А. А. Столяр. Мн. : Выш. шк., 1986. - 414 с. 7. Фридман Л. М. Наглядность и моделирование в обучении / Л. М. Фридман. - М. : Знание, 1984. - 80 с. 8. Фридман Л. М.Педагогический опыт глазами психолога :[книга для учителя] / Л. М. Фридман. - М. : Просвещение, 1987. - 224 с. 9. Шевченко С. Д. Школьный урок : как научить каждого / С. Д. Шевченко. - М. : Просвещение, 1991. - 175 с.

УДК37.02(09)(477)

Вадим Пилипенко

\title{
«ЛЕКЦИИ ИМЕЮТ БЫТЬ ЧИТАННЫМИ...» (ДО ПИТАННЯ ОРГАНІЗАЦІЇ О. СТРОНІНИМ ПУБЛІЧНИХ ЧИТАНЬ У ПОЛТАВІ)
}

Пилипенко В. В. «Лекции имеют быть читанными...» (до питання організації О. Строніним публічних читань у Полтаві).

Стаття присвячена освітній діяльності Олександра Івановича Строніна у сфері поширення практики читання публічних лекцій. Обгрунтовуються педагогічні, організаторські та адміністративні здібності вчителя в розглядуваному освітньому напрямі. Акцентується увага на тому, що О.Стронін розглядав публічні лекції як цілісний та самобутній проект позашкільної освіти.

Ключові слова: О. Стронін, жіноча гімназія, навчання, недільна школа, публічні лекції.

Пилипенко В. В. «Лекции имеют быть читанными...» (к вопросу организации А. Строниным публичных чтений в Полтаве).

В статье рассматривается деятельность Александра Ивановича Стронина в сфере распространения практики чтения публичных лекций. Обосновываются педагогические, организаторские и административные умения учителя в данном образовательном направлении. Акцентируется внимание на том, что А. Стронин рассматривал публичные лекции как целостный и самобытный проект внешкольного образования.

Ключевые слова: А. Стронин, женская гимназия, обучение, воскресная школа, публичные лекции.

Pilipenko V. V. «Lectures are to be read ...» (to the organization A. Stronina public readings in Poltava).

The article about A. Stronin`s educational activity in the field of public lectures. Author is substantiated pedagogical, organizational and management teachers ability as public lectures founder. Attention is accented on that A. Stronin considered the public lectures as holistic and original project of out of School Educational.

Key word: A. Stronin, Sunday school, women's gymnasium, education, public lectures,.

Одними із пріоритетних принципів реалізації Державної національної програми «Освіта» («Україна XXI століття») визначено іiі багатоукладність і варіантність, щопередбачає створення можливостей для широкого вибору форм освіти, засобів 
навчання і виховання, які відповідали б освітнім запитам особистості, запровадження варіантного компонента змісту освіти, диференціацію та індивідуалізацію навчальновиховного процесу. Але сучасна українська освіта, поринувши в запровадження інновацій, відчуває різкий брак досвіду і можливостей повноцінної реалізації означених принципів. Причиною останнього є недостатнє звернення до вітчизняного історикопедагогічного досвіду як джерела реформування освітньої галузі. Адже в історії є багато самобутніх прикладів урізноманітнення навчально-виховного процесу та виведення освіти за межі традиції. Одним із таких було запровадження наприкінці 50 - на початку 60 років ХІХ століття О. Строніним читання публічних лекцій у м. Полтава.

Значний обсяг наукових досліджень, присвячених розвитку вітчизняної освіти XIX століття, не надає цілісної картини створення і розвитку публічних читань у Полтаві. У цьому контексті є лише несистематизовані згадки про активну діяльність О. Строніна в цій галузі та сам факт започаткування читань. Зокрема, російська дослідниця В.Лейкіна-Свірськая, відзначаючи педагогічні здібності О.Строніна, згадує і прочитані ним разом із Д. Пильчиковим лекції, не зупиняючись на їх сутності. Сучасна українська дослідниця Т. Бевз, аналізуючи наукову діяльність О. Строніна, зазначає, що він був засновником народних лекцій у контексті опублікованого вчителем циклу книг «Народна енциклопедія». Краєзнавець I. Петренко наголошує на провідній ролі полтавської громади та меценатства Є. Милорадович у започаткуванні читань. Як бачимо, порушена автором статті проблема залишається донині не розв'язаною та потребує грунтовного аналізу.

Mema cmammi- дослідження організації О.Строніним публічних читань у Полтаві на початку 60-х років XIX століття.

Виходячи з актуальності роботи, сформулюємо її основні завдання: а) визначити роль О.Строніна у створенні та впровадженні досліджуваних форм освітньої взаємодії; б) проаналізувати організацію та діяльність публічних читань у Полтаві як єдиний цілісний просвітницький проект.

Олександр Іванович Стронін - відомий педагог-новатор середини XIX століття. Після закінчення Київського університету Святого Володимира в 1848 році він розпочав активну просвітницько-педагогічну діяльність [8, с. 33]. Стрімке кар'єрне зростання молодого вчителя змінювалося каскадом невдач. Зокрема, після вдалого кар'єрного початку у Кам'янець-Подільській, а згодом і в Немирівській гімназіях настав період щорічного переведення на нові посади. О. Строніна з 1853 до 1855 років переводили до Костянтиноградського повітового училища, згодом до НовгородСіверської гімназії. Доленосним у житті педагога стало призначення його на посаду старшого вчителя Полтавської гімназії, коли він отримав можливість повною мірою зреалізувати свій педагогічний потенціал [8, с. 34]. Не бажаючи обмежувати освітню діяльність винятково гімназійними заняттями, О. Стронін розгорнув широку просвітницьку діяльність. Він був організатором Товариства поширення грамотності в народі, ініціював відкриття недільних і суботніх (для єврейського населення) шкіл, створив народний театр, популяризував у місті ідею всезагальної освіченості, поширював актуальну в ті часи літературу, зокрема й українських авторів [8, с. 3638]. Надзвичайний суспільний резонанс був спровокований ще одним напрямом освітньої діяльності педагога. Наприкінці 50-х років XIX століття за його безпосередньої участі в Полтаві було розпочато читання публічних лекцій. До цього нечуваний у місті захід отримав популярність серед значної частини населення. Про читання повідомляла місцева преса, міська інтелігенція активно долучалася до їхньої організації, а слухачами ставали представники різних прошарків населення: від 
місцевих учнів до малограмотних людей старшого віку.

Задля визначення мети започаткування практики публічних читань доцільною $є$ актуалізація безпосередньої ролі О. Строніна в їхній діяльності. Дізнавшись останнє, ми матимемо змогу відштовхуватися від об'єктивних чи суб'єктивних процесів, що детермінували до виникнення ідеї та початку реалізації цього проекту.

У сучасній історико-педагогічній літературі постать О. Строніна розглядається неоднозначно. Педагог працював у Полтаві в часи активної діяльності місцевої громади. Він неодноразово підпадав під критику як від офіційної влади за свою «ліберальність», так і від представників місцевої інтелігенції, які докоряли освітянину за його російське походження і недостатню відданість українській справі [3, с. 169]. Не дивно, що й сучасні дослідники, користуючись мемуарними джерелами, піддають критиці постать О. Строніна, залишаючи його на другому плані порівняно $з$ іншими полтавськими громадівцями.

Для нас важливим $є$ саме освітній аспект цього питання. Тому слід звернути увагу на офіційну документацію середини XIX століття, яка й дає відповідь щодо постаті ініціатора започаткування публічних читань. У ході дослідження було виявлено, що офіційне листування О. Строніна з попечителем Київського навчального округу М. Пироговим та міністром народної освіти Є. Ковалевським розпочалося 1859 року і продовжувалося до кінця 1861 року. Це були роки надзвичайно плідної діяльності педагога в Полтаві. До того ж, незалежно від авторства ініціатив, у листах протягом цих двох років незмінно зазначалося: «... все заботы взял на себя А. Стронин...» $[12$, с. 1]. Як бачимо з архівних даних, питання організатора публічних читань у Полтаві розв'язується однозначно і стає повністю зрозумілим, що ї проведення стало наслідком просвітницьких ініціатив О. Строніна.

Підтвердивши провідну роль в організації публічних читань О. Строніна, маємо можливість визначити основну мету їхньої діяльності. Олександр Іванович завжди працював відповідно до вимог суспільства. Він наголошував, що педагог завжди повинен експериментувати, пробувати щось нове, постійно перебувати в творчому пошукові [8, с. 37]. Тому і сам учитель часто брався за нові методи поширення освіти серед населення.

Слід наголосити на тому, що і суспільство вимагало докорінних змін в освітній сфері. Педагог-новатор був символом надії для більшості неосвіченого населення, що вимагало не тільки реформування економічного життя, а значного підняття рівня власної освіченості [2, с. 8]. Гостро поставала проблема концептуальних змін в освітньому середовищі. Адже, окрім традиційного реформування діючих навчальних закладів до вимог часу (підготовка педагогічних кадрів, уніфікація системи освіти тощо), був й інший бік суспільної вимоги - навчання широких мас неосвіченого або малоосвіченого дорослого населення. Нині опубліковано багато суперечливих даних щодо кількості освіченого населення в Російській імперії на середину XIX століття, але амплітуда статистичних коливань залишається в межах 5-10\% населення [6, с. 285-288]. Такі дані свідчать про критично низький рівень грамотності в країні та відверту неготовність значної частини населення до глибокого реформування суспільного життя.

Це добре розуміли передові педагоги, до яких належав і О. Стронін. Він ініціював трансформаційні процеси в освіті «знизу». Отже, можна стверджувати, що започаткування публічних лекцій у Полтаві мало два провідні чинники: а) особиста професійна ініціатива О. Строніна та б) гостра суспільна вимога реформування освіти задля подолання низького рівня грамотності населення.

Започаткування публічних читань було дуже складною справою. Окрім 
традиційних адміністративних перепон, на які, зазвичай, наштовхувалася передова інтелігенція, О. Стронін зіткнувся ще й зі значним дефіцитом педагогічних кадрів. У середині XIX століття на українських землях не було спеціалізованих навчальних закладів, де б готували вчителів [1, с. 99]. Упровадження нової галузі позашкільного навчання було поділене О. Строніним на два етапи. Першим етапом стали публічні читання з актуальних навчальних дисциплін у Полтавській жіночій гімназії, що мали за мету підготувати додаткові вчительські кадри. Другим - загальнонародні читання, що почали впроваджуватися з 1861 року.

Такий розподіл на етапи не був випадковим. О. Стронін шукав найоптимальнішого варіанту реалізації запланованих ініціатив. Спочатку необхідно було б створити сприятливе середовище як у Полтаві, так і серед освітніх діячів імперії. Саме тому перші публічні читання, на думку О. Строніна, мали відбутися в Полтавській жіночій гімназії. Він не виносив на загальний розсуд основної мети цього заходу. Навпаки, педагог обгрунтовував їх проведення винятково розширенням компетентностей вихованок. Тому до програми було внесено три предмети: технології, педагогіку та хімію. Вони мали безпосередній прикладний характер і відповідали вимогам часу. Зокрема, учитель Гаєвський (ім'я невідоме) повинен був прочитати лекції 3 технологій, у ході яких планувалося розкрити проблему використання палива в домашніх умовах. Окрема частина лекції присвячувалася правилам користування гасовою лампою як одним із нових пристроїв для освітлення приміщень [12, с. 3]. Для наукового обгрунтування поданого матеріалу під час прослуховування лекцій 3 технології були заплановані заняття 3 хімії, які проводив Казимовський (ім'я невідоме). На них вихованкам розповідалося про хімічні властивості горіння та води [12, с. 4]. На переконання О. Строніна, такі теми лекцій повинні бути корисними майбутнім господиням, які б, отримавши хорошу освіту, мали й практичні навики користування новими приладами.

Провідним курсом публічних лекцій для вихованок жіночої гімназії була педагогіка. Не зважаючи на те, що О. Стронін на першому етапі своєї діяльності в цій галузі займався тільки організаційними питаннями, він досить прискіпливо ставився до матеріалу лекцій, повністю контролюючи підготовку та неодноразово долучаючись до його розроблення.

Програма лекцій з педагогіки була пронизана ідеєю єдності навчання і виховання особистості. У ній наголошувалося, що в основі життя людини лежать два головні принципи: а) суспільність (життя людини на користь розвитку суспільства); б) постійний освітній саморозвиток («perfecti bility») $[12$, c. 3]. У програмі наголошувалося, що в основі виховної системи повинна бути ідея створення всебічно і гармонійно розвиненої особистості. Досягнення поставленої мети можливе лише за умов єдності фізичного та морального виховання людини. Найкраще, щоб ідеї одного проступали через методи іншого і навпаки.

Оскільки лекції повинні читатися в жіночій гімназії, то особлива увага приділялася ролі жінки в історичному розвитку людства. Педагоги ставили за мету показати, що саме жінка завжди була на чолі виховання нового покоління. Наголошували на i виключній ролі в майбутньому та на гострій необхідності іiі освітнього зростання як основи розбудови громадянського суспільства [12, с. 4]. Програма педагогічних читань мала стратегічну мету підготовки освітніх кадрів, але про неї не йшлося в жодному з офіційних документів, що були подані О. Строніним для отримання дозволу на проведення читань.

Такого роду освітня ініціатива мала пройти складну бюрократичну систему від 
Директора училищ Полтавської губернії до міністра народної освіти. Кожна ланка давала рекомендації та ставила санкцію на дозвіл проведення. Тому 3 часу подачі офіційної заявки на започаткування читань (20 жовтня 1859 року) до офіційного дозволу на їхнє читання минуло понад п’ять місяців. Зрештою, 26 лютого 1860 року міністр народної освіти Є. Ковалевський дав офіційний дозвіл на читання публічних лекцій $[12$, с. 6]. Із цього часу розпочався новий етап в освітній діяльності О. Строніна. Педагог, отримавши позитивну відповідь, активно почав упроваджувати означений проект і розробляти нові освітні ініціативи.

Зрештою, лекції були прочитані навесні 1860 року під час Великого посту [12, c. 3]. Значного резонансу в місті вони не набули, оскільки фактично стали закритим заходом, хоча й передбачалося їхнє відвідування всіма бажаючими. Але О. Стронін і не ставив за мету розширення саме цього циклу в загальноміських масштабах. Провівши ці лекції, учитель отримав позитивний досвід і авторитет серед місцевої інтелігенції. До того ж кожен новий проект потребував позитивної апробації. Отже, О. Стронін зумів показати активістам полтавської громади, що проведення публічних читань є можливим.

Успіх першого етапу впровадження публічних читань надав О. Строніну впевненості. Він відразу взявся за реалізацію другого етапу, який мав перейти в діючі недільні школи. Складність його полягала в тому, що програма читань повинна бути адаптованою для людей різного рівня грамотності та виходити з різноманітності їхніх інтересів. 3 іншого боку, потрібно було знову пройти всю освітню бюрократичну систему, щоб отримати дозвіл на їхнє читання. Учитель підготував офіційне звернення, обгрунтувавши практичну потребу створення таких читань. Відповідь міністра була позитивною, і О. Стронін розпочав підготовку до другого етапу.

На цьому етапі значно складніше вирішувалося питання кадрового забезпечення авторів лекцій, адже попередні лекції проходили на комерційній основі і мали ціну 25-50 копійок $[12$, с. 3]. Читання в недільних школах не могли проходити за суворо встановленою ціною, хоча на це й була вимога у звітній документації. Цільову аудиторію, на яку спрямовувалися ці заходи, в основному складали середньостатистичні жителі Полтави, які не завжди могли відшкодувати такі заходи. Зрештою, О. Стронін установив символічну ціну за одну прослухану лекцію - вона складала три копійки 3 одного відвідувача [7, с. 338]. Але за таких умов необхідно було шукати учителівентузіастів, які б погодилися посприяти в реалізації ініціативи О.Строніна. Педагог звернувся за допомогою до свого колеги Д. Пильчикова, який і раніше відзначався особистим інтересом до народної освіти [4, с. 53]. Отже, проведення публічних читань стало прерогативою двох відомих у Полтавській губернії учителів історії, які довгий час плідно співпрацювали у сфері народної освіти.

Програма лекцій охоплювала низку суспільних і природничих наук. Відомо, що О. Стронін та Д. Пильчиков читали основи природознавства, географію, фізику, астрономію, економіку та суспільствознавство (частиною якого була історія) [5, с. 86]. Як обгрунтовували в тогочасній періодиці, лекції проводилися 3 тих дисциплін, «що потрібно знати кожному» [4, с. 53]. Незважаючи на суспільно-гуманітарну підготовку вчителів, вони представляли значну частину тодішніх наукових знань, щоб подати учням необхідний для їхнього інтелектуального становлення матеріал. Кожен такий захід вимагав від педагога окремої підготовки відповідно до інтересів слухачів і актуальності теми. Тому задля підвищення якості читань педагоги домовилися по черзі готувати заняття та проводити їх одноосібно [4, с. 53]. Окрім них, лекції читали О. Кониський, І. Щитинська та інші [5, с. 86]. 
Періодичність занять обиралася відповідно до можливостей педагогів і слухачів. Учителі працювали в кількох навчальних закладах по буднях, тому не мали можливості серед тижня проводити такі читання. Більшість слухачів були дорослими і також мали вільний час тільки у вихідні. Найзручнішим днем для читань була неділя, яку й обрали для їх проведення.

Час початку лекцій визначався з урахуванням розпорядку дня середньостатистичних полтавчан. Адже часто для багатьох жителів міста неділя асоціювалася із відвідинами церкви, ярмарків, іншими публічними заходами. О. Стронін ініціював розпочинати читання 3 п'ятнадцятої години $[5$, с. 86$]$. Цей час педагог уважав найзручнішим для багатьох потенційних слухачів, яким не потрібно було вносити серйозних змін у традиційний недільний розпорядок.

О. Стронін, як основний ініціатор проведення публічних читань, узяв на себе відповідальність щодо організації внутрішнього розпорядку заходів. Так, він, виходячи із власного педагогічного досвіду, встановив чіткий час для проведення лекцій. Кожна 3 них обмежувалася однією годиною [5, с. 86]. За цей час лектор повинен був повністю та зрозуміло викласти тему заняття та дати відповіді на запитання, що зацікавили слухачів. Звісно, такий підхід був пов'язаний із можливостями більшості слухачів, які до цього не мали досвіду довготривалої інтелектуальної роботи.

Народні читання розпочалися першого жовтня 1861 року [4, с. 53]. Суспільний ажіотаж здивував навіть організаторів заходу, адже значна частина жителів Полтави і навколишніх населених пунктів виявила бажання відвідати читання [4, с. 53]. О. Стронін описав одну 3 перших лекцій у своїй брошурі «Розповіді про людське життя». Педагог згадував, що серед слухачів переважали прості селяни і міщани. Щоправда, серед присутніх були священики, поміщики і представники освітньої адміністрації губернії [9, с. 4]. Їхня присутність пояснювалася різними причинами: від банальної цікавості до пошуку причини надіслати скаргу на антидержавну діяльність О. Строніна.

Популярність серед простого населення викликала неймовірне захоплення серед полтавської інтелігенції. Свою повагу започаткованій О. Строніним справі висловлювали на сторінках провідних українських періодичних видань. Зокрема, О. Кониський (під псевдонімом Олександр Переходовець) у статті, надрукованій у журналі «Основа», схвально відзначав діяльність О.Строніна в започаткуванні народних читань, наголошуючи як на просвітницькій ролі заходу, так i на організаторських здібностях самого педагога [4, с. 53].

Суспільний успіх другого етапу впровадження народних читань стимулював О. Строніна до розширення предмета діяльності. Педагог вирішив зробити значно радикальніший крок порівняно з попередніми та подати прохання про проведення нового циклу публічних лекцій у недільних і суботніх (єврейських) школах зі всесвітньої історії [10, с. 1]. Вони мали бути присвяченими історії Франції першої половини XVIII століття. За відносно невинними темами, що розкривали придворне життя часів регентства Філіпа Орлеанського та інтриги навколо заповіту Людовіка $\mathrm{XIV}$, був прихований цикл тем радикального змісту. Так, назвавши тему «Література», О. Стронін вніс туди огляд основних творів Вольтера, Ж. Ж. Руссо, Ш.-Л. Монтеск'є та інших просвітників [11, с. 3]. У кінці програми педагог пропонував обговорювати зі слухачами соціальні процеси у Франції XVIII століття, аналізувати становище третього стану [11, c. 3]. Такий зміст лекцій мав провокаційний характер навіть для часів початку Великих реформ. Проте, програма 
була погоджена 3 попечителем Київського навчального округу та визнана «задовільною» комісією Київського університету $[11$, с. 2]. Але міністр народної освіти відмовив у можливості читання таких лекцій, пояснивши відірваністю їх від потреб слухачів. Згодом аналогічне зауваження було висловлене й попечителем Київського навчального округу $[11$, с. 2]. О. Стронін боровся за можливість прочитання такого типу лекцій, намагався трансформувати програму, але результату це не дало. Із початком 1862 року на педагога посилився адміністративний тиск, що вилився у його звільнення 3 посади старшого вчителя чоловічої гімназії та арешту [13, c. 5]. Зазначені події не дозволили довести до кінця започатковану справу.

Отже, проведене дослідження надає достатньо грунтовні підстави стверджувати, що ініціатором та головним організатором перших в Україні публічних читань був О. Стронін. Немає сумніву, що вчитель планував ці заходи як цілісний і самобутній проект позашкільної освіти, що був реалізований у два етапи: а) лекції в жіночій гімназії; б) читання в недільних школах. Перший етап мав метою підготувати педагогічні кадри для новостворених навчальних закладів, кількість яких щорічно збільшувалася за рахунок активної діяльності українських громад. Другийбезпосередньо пов'язаний із процесом поширення освіти серед населення i популяризації основ наукових знань.

На жаль, через цензурні утиски О. Стронін не зміг повною мірою реалізувати весь свій потенціал. Але започаткована ним справа отримала розвиток у поширенні народних читань по всій території Російської імперії, що в другій половині ХІХ століття стали одним із найпопулярніших видів позашкільного освіти.

\section{Література}

1. Андрійчук Н. Підготовка вчителів народної школи в учительських семінаріях України (1860-1917 рр.)/ Н. Андрійчук. - Житомир : Вид-во ЖДУ, 2011.297 с.2. Богуславский М. Реформы российского образования XIX-XX вв. как глобальный проект / М. Богуславский // Вопросы образования. - 2006. - № 3. - С. 521. 3. Дудко В. Полтавська громада початку $1860-\mathrm{x}$ років у листах Дмитра Пильчикова до Василя Білозерського / В. Дудко // Київська старовина. - 1998. - № 2. - С. 155-179.4. Кониский О. Зъ Полтави (1 января 1862)/ О. Кониский: [Стат.] О. Переходовець [псевд.] // Основа. - 1862. - № 2. - С. 52-54. 5. Петренко I. Слизавета Милорадович (1832-1890) в українському суспільно-політичному pусі : [монографія] / І П. Петренко. - Полтава: ПУЕТ, 2013. - 151 с. 6. Рашин А. Население России за 100 лет (1811-1913 гг.) / А. Рашин: [под. ред. С. Струмилина]. М : Государственное статистическое издание, 1956. - 352 с. 7. Сірополко С. Історія освіти в Україні / С. Сірополко: [підгот. Ю. Вільчинський]. - Львів: Афіша, 2001. 664 с. 8. Стронин А. Дневник с 1848 по 1888 годы / А. Стронин. - Т. 1 (1863-1864) [2й вариант] // ОР РНБ г. Санкт-Петербурга. - ф. 752. - д. 3. - 47 стр. 9. Стронин А. Рассказы о человеческой жизни / А. Стронин: [Соч.] Александра Иванова [псевд.] Санкт-Петербург: Тип. Ф. Сущинского, 1873. -70 c.10. Центральний державний історичний архів (м. Київ) (далі: ЦДІАК). - ф. 707. - оп. 27. - спр. 21. - О дозволении учителям Полтавской гимназии Стронину, Вакуловскому и Фененку прочесть несколько публичных лекций (9 января 1861 года). - 15 с. 11. ЦДІАК. - ф. 707. - оп. 27. - спр. 273. - О дозволении учителю Полтавской гимназии Стронину читать публичные лекции по всеобщей истории (6 июня 1861 года). - 12 с. 12. ЦДІАК. ф. 707. - оп. 25. - спр. 472. - О разрешении на открытие в городе Полтаве публичных лекцій по технологии, педагогике и химии (20 октября 1859 года). - 9 с. 13. ЦДІАК. ф. 707. - оп. 28. - спр. 318. - Об увольнении от службы учителя Полтавской гимназии 
Стронина и о выдачи ему единовременного пособия. -5 с.

УдК: $378.013+315.6+351.8$

Ірина Ткачук

\section{СУТНІСТЬ І СТРУКТУРА ФЕНОМЕНУ «ІНТЕРПРЕТАЦІЙНА КОМПЕТЕНТНІСТЬ СТУДЕНТІВ ПЕДАГОГІЧНОГО КОЛЕДЖУ»}

Ткачук I. О. Сутність і структура феномену «інтерпретаційна компетентність студентів педагогічного коледжу».

У статті розглянуто поняття «інтерпретаційна діяльність», «інтерпретаційна компетентність»; розкрито сутність i структуру феномену «інтерпретаційна компетентність студентів педагогічного коледжу». Визначено, що структура інтерпретаційної компетентності студентів педагогічного коледжу містить аксіологічний, когнітивний, діяльнісно-творчий та рефлексивний складники з певними показниками.

Ключові слова:інтерпретаційна діяльність, інтерпретаційна компетентність, складники інтерпретаційної компетентності майбутніх учителів.

Ткачук И. А. Сущность и структура феномена «интерпретационная компетентность студентов педагогического колледжа».

В статье рассмотрены понятия «интерпретационная деятельность», «интерпретационная компетентность»; раскрыты сущность и структура феномена «интерпретационная компетентность студентов педагогического колледжа». Определено, что структура интерпретационной компетентности студентов педагогического колледжа содержит аксиологическую, когнитивную, деятельностнотворческую и рефлексивную составляющие с определенными показателями.

Ключевые слова:интерпретационная деятельность, интерпретационная компетентность, составляющие интерпретационной компетентностибудущих учителей.

Tkachuk I. O. Essence and structure of the phenomenon of «interpretational competence pedagogical college students».

The article deals with such notions as «interpretative activity», «interpretative competence»; discloses the nature and structure of the phenomenon of «interpretative competence of students of pedagogical college». It is defined that the structure of interpretative competence of students of pedagogical college contains axiological, cognitive, activity-creative and reflective components with specific characteristics.

Key words:interpretative activity, interpretative competence, components of future teachers' interpretative competence.

В умовах сьогодення значної актуальності набуває проблема формування інтерпретаційної компетентності майбутніх учителів, оскільки спрямованість на розуміння багатоаспектності та багатомірності наукових знань i педагогічних процесів розширює функції професійної діяльності вчителя. Це виявляється в уміннях поширювати контексти засвоєння педагогічних знань, діяти в умовах свободи вибору змісту та форм освіти, самостійно організовувати свою навчальну діяльність $i$, отже, не просто практично володіти навчальними діями, але й рефлексивно, усвідомлюючи сутність і підгрунтя виконуваних дій, оцінюючи їх відповідність цілям та умовам діяльності і визначаючи на цій підставі найбільш ефективні способи інтерпретації знань.

У педагогічних дослідженнях можна виокремити такі напрями наукового Педагогіка вищої та середної школи. - 2014. - Вип. 41 